\title{
Challenges in Raw Material Treatment at the Mechanical Processing Stage
}

\author{
Daniel Saramak
}

check for

updates

Citation: Saramak, D. Challenges in Raw Material Treatment at the Mechanical Processing Stage. Minerals 2021, 11, 940. https:// doi.org/10.3390/min11090940

Academic Editor: Thomas Mütze

Received: 24 July 2021

Accepted: 25 August 2021

Published: 29 August 2021

Publisher's Note: MDPI stays neutral with regard to jurisdictional claims in published maps and institutional affiliations.

Copyright: (C) 2021 by the author. Licensee MDPI, Basel, Switzerland. This article is an open access article distributed under the terms and conditions of the Creative Commons Attribution (CC BY) license (https:/ / creativecommons.org/licenses/by/ $4.0 /)$.
Department of Environmental Engineering, Faculty of Civil Engineering and Resource Management, AGH University of Science and Technology, 30-059 Cracow, Poland; dsaramak@agh.edu.pl

\begin{abstract}
This paper concerns problems related to the mechanical processing of mineral raw materials. The aspects explored were limited to the analysis of comminution technologies in terms of their effectiveness and energy consumption, modeling and simulation approaches, the assessment of crushing results, and environmental aspects. This article includes investigation of new technologies of comminution, comparing HPGR, high-voltage pulses, and electromagnetic mills. In the area of modeling and optimization, special attention was paid to the approximation of the particle size distribution of crushing products by means of Weibull, log-normal, and logistic functions. Crushing products with an increased content of fines were well characterized by Weibull's distribution, while log-normal function adequately described HPGR products with a relatively low content of fines.
\end{abstract}

Keywords: raw materials; mineral processing; enrichment; comminution; HPGR; approximation of particle size

\section{Introduction}

The processing technology used for mineral raw materials is crucial in terms of the production of numerous metals and non-metallic products sourced and extracted by means of mining techniques. Though the entire value chain of metal production includes a number of steps (from geology, through to mining, metallurgy, and manufacturing), the mineral processing stage, to some extent, influences the quality of the final product and the effectiveness of the entire process of commercial product manufacturing. Despite its complexity and the application of many physical, mechanical, chemical, and other types of separation processes and operations, ore mineral processing can generally be divided into two overarching stages:

(a) reduction in the size of the feed material;

(b) separation of useful mineral from the gangue.

The primary purpose of the size reduction stage is the liberation of useful mineral in a way that allows for proper separation in the downstream separation stage. This process for the case of ores is presented in Figure 1. The ROM (run-of-mine) material is a mix of compounds of ferrous or non-ferrous metals and gangue. Useful elements and compounds (black color on Figure 1) are "locked" among the gangue material in the ROM. In such a form, it is rather difficult to separate them from the gangue with high efficiency. Through the application of comminution operations, the size of individual particles can be made finer and thus the liberation of useful compound is more intense compared to the ROM material (center of Figure 1). Compared to non-crushed ores, the separation of such materials can be carried out in a less complicated manner and higher recoveries can be achieved. The separation product contains a significant amount of useful compounds (lower part of Figure 1). This situation applies to ore enrichment, which are generally divided into ferrous and non-ferrous minerals (i.e., cupriferous, gold or silver-bearing, and other metals except for iron). 


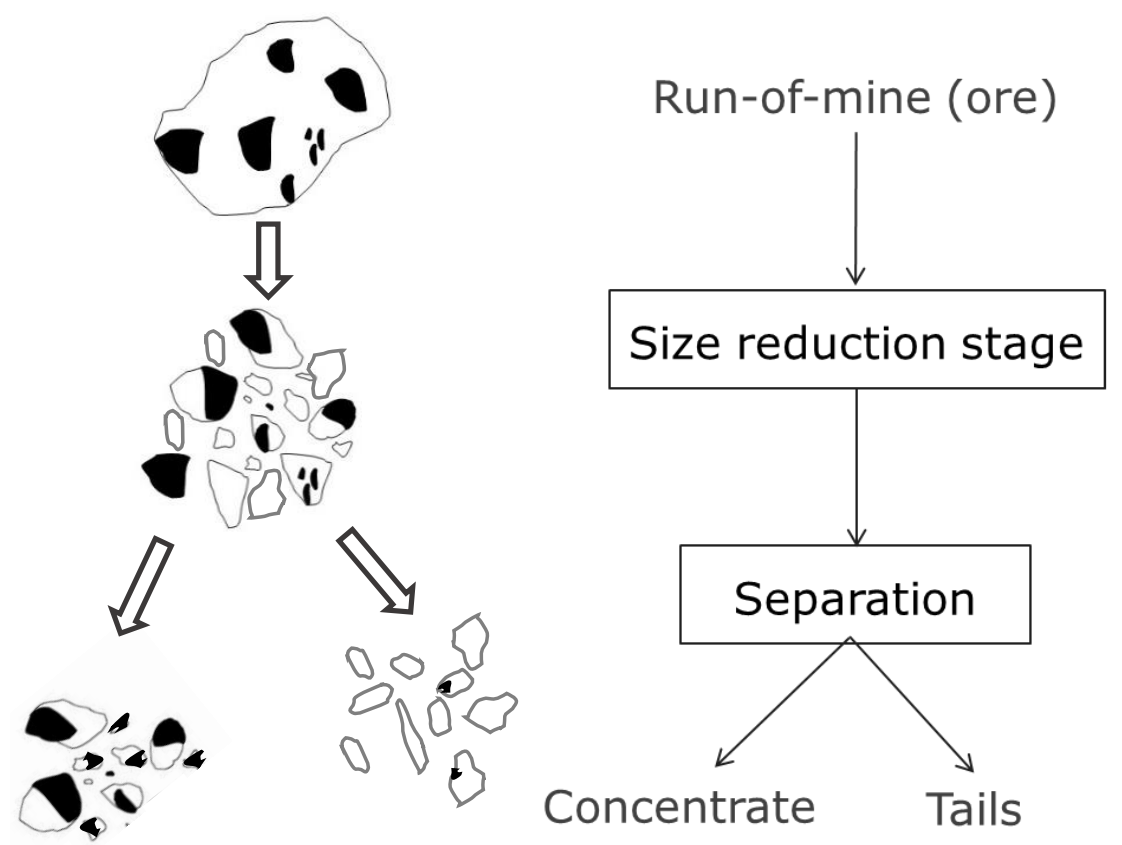

Figure 1. Mineral processing for metal-bearing ores.

In both aggregates production and the processing of rock materials, (such as crushing stones, sands, and gravels), the stage of size reduction (comminution) constitutes the primary step. This directly influences the qualitative parameters of final products in terms of size and shape (aggregate production sector) or specific surface (cement clinker industry) [1].

Considering previous text, the mechanical processing of raw materials is a crucial stage in the technology of both ore processing and the aggregate production sector. Proper passage through this stage initially influences the potential effectiveness of the core beneficiation operations of minerals from the scope of useful mineral recovery, and much research has been carried out in this area. Current trends in these investigations mainly include:

- development of new comminution technologies;

- $\quad$ optimizing the performance of recent applications;

- modeling, simulation, and performance optimization of mechanical processing circuits.

Recently, environmental aspects have been gaining greater attention, especially in terms of decreasing the negative impact of mechanical processing operations on the environment and society; in particular, attention has been paid to harmful and annoying emissions of dusts, gases, heat, and noise. Operations of industrial comminution account for as much as 3\% to 5\% of the total usage of electric energy in the world [2]. Despite this, their performance effectiveness is relatively low and has an inverse relationship to the size of the crushed material. For example, the energetic efficiency of tumble mill operation is estimated to be around 15\%. Meanwhile, the production efficiency of some types of very fine grinding products can be as low as 1\% [3]. Comminution energy utilization is higher in crushers, particularly in impact crushers. However, it is dependent on the type of raw material used and the crushing stage within the technological circuit [4]. Research generally confirms that crushing uses between 0.5 and $1 \mathrm{kWh} / \mathrm{Mg}$, and that crushing devices using attrition and shear forces consume between $40 \%$ and $80 \%$ more comminution energy than machines based on impact forces [5]. Compression and impact forces techniques in material disintegration save the most energy. However, the low energy utilization for a breakage mechanism in conventional crushing and grinding equipment leads to the development of innovative comminution technologies [6]. 


\section{Development in Crushing and Grinding Technology}

\subsection{HPGR Technology}

HPGR devices are considered one of the most energy-efficient comminution machines. However, despite their lengthy existence in industrial mineral processing circuits, there have been many research projects aimed at improving their operational performance. While HPGRs indisputable energetic benefits have been largely proven in the literature $[7,8]$, results from more recent investigations show room for improvement in both separation in flotation and leaching processes [9-11], mostly due to the intense liberation of useful mineral [12].

The average unit energy consumption for HPGR devices varies between 2 and $3-4 \mathrm{kWh} / \mathrm{Mg}$; however, this depends on the mechanical properties of the material, the equipment size, and the recirculation scheme of the HPGR feed and product. Industrial practice shows that in calculations the value of $2.5 \mathrm{kWh} / \mathrm{Mg}$ is quite often accepted. Compared to tertiary crushing devices, applying HPGR to the comminution circuits of ore lowers grinding energy by $20 \%-30 \%$ in downstream operations.

In the SAG-based grinding circuit, the ball mill grinding energy consumption is comparable to the grinding energy used in mills following the HPGR. However, the overall energy reduction in a HPGR-mill configuration can be greater than $30 \%$. The benefits of HPGR in mineral beneficiation are visible at the level of useful mineral liberation. Microscopic analysis has found [12] values of $75 \%$ to $95 \%$ for copper minerals liberated from sulfide ores, depending on the operating pressure value. Copper recovery in downstream flotation varies from $80 \%$ to $85 \%$, while the same value for ore that has been conventionally crushed (i.e. without using of high-pressure technology) is $80 \%$. HPGR is beneficial in the recovery of minerals, as well as in leaching and cyaniding operations. Copper extraction from sulfide ores was $2 \%$ to $8 \%$ higher when leaching from HPGR-based circuit products, and kinetic readings of the process were more favorable [13]. Comparable effects are evident when heap leaching other minerals from upstream ores treated by HPGR. The metal extraction rate for HPGR is $10 \%-15 \%$ higher than that of conventional crushing devices [14].

\subsection{High Voltage Breakage}

Investigations into improving the efficiency of breakage energy led to the development of other innovative techniques of comminution. High-voltage electrical pulse technology helps to achieve more intense liberation in ore comminution. The efficiency of this technique greatly depends on the regime of pulsation, as well as the texture and mechanical and electrical properties of the ore material. The optimization of pulse parameters is considered a very significant issue; however, it also creates problems, and a pulse generator dedicated especially to mineral liberation should be used [15]. Laboratory practice shows that if electric pulses are not adjusted to the material properties, there is no improvement in the effectiveness of liberation compared to using mechanical comminution techniques. In one example, gold ore which had been treated upstream by electric pulses did not record significantly improved extraction compared to mechanical breakage. However, after the optimization of the pulsating regime, the gold recovery was 35\% higher due to the more intense liberation [16].

Gold recovery in cyanidation can be $15 \%-50 \%$ higher than in that in ores that have been mechanically ground; however, this depends on the material's properties. In some cases, a $60 \%-70 \%$ recovery can be observed.

Lower rates of metal recovery in flotation can be found; however, some results show that up to a $20 \%$ higher concentration of metal can be obtained in tail flotation following high-voltage pulses. Estimates of the unit energy consumption for the high-voltage pulse technique show that it varies from 3 to $5 \mathrm{kWh} / \mathrm{Mg}$. There are relatively few publications in world scientific databases concerning investigations on the using of high-voltage pulses in comminution. The bibliometric analysis of the Core collection of Web Science database 
searching for the terms "high voltage pulses" and "comminution" or "liberation" shows that 100 publications have been published on this topic since 2012.

\subsection{Electromagnetic Mills}

The grinding technology used in electromagnetic mills is a novel method of material disintegration that utilizes rotating electromagnetic fields [17]. Fast-moving grinding media in the shape of short rods, made of ferromagnetic material, cause material breakage in the working chamber. Laboratory tests confirm the very short duration of the process; it requires from several to few tenths of seconds to prepare a $500 \mathrm{~g}$ sample for flotation operation. In terms of comminution ratio, the achieved results are very good compared to those achieved using conventional tumbling mills, thus the level of liberation is also higher. The technology is relatively new; only 50 publications can be found in international scientific databases, with nearly $75 \%$ issued within the last 5 years. Similarly to high-voltage pulses, the main issue is the lack of full-scale plant installation. However, in this case a quarter-scale machine is available. No test results for ore beneficiation in hydrometallurgy operations for electromagnetic mill products have been obtained so far; however, the results of flotational separation for sulfide copper ore show copper recovery increased by about $10 \%-15 \%$ compared to conventional crushing and grinding devices. It is, however, difficult to find indisputable evidence for overall separation improvement, especially at the semi-plant and plant scale; however, it seems that for some specific purposes, the technology may bring be beneficial.

Table 1 summarizes the three characterized technologies for raw material comminution in terms of their capacity, energy consumption, and technological effectiveness.

Table 1. Summary of the benefits of HPGR, electric pulse breakage, and electromagnetic mills.

\begin{tabular}{ccccc}
\hline Type of Benefit & Unit & \multicolumn{3}{c}{ Type of Comminution Technology } \\
\cline { 3 - 5 } & & HPGR & Electromagnetic Mill & Electric Pulses \\
\hline $\begin{array}{c}\text { Unit energy consumption } \\
\text { Benefits in mineral liberation compared to } \\
\text { conventional crushing }\end{array}$ & $\mathrm{kWh} / \mathrm{Mg}$ & $2-4$ & $50-150$ & $3-5$ \\
$\begin{array}{c}\text { Benefits in useful mineral recovery } \\
\text { compared to conventional } \\
\text { crushing: hydrometallurgy }\end{array}$ & $\%$ & $10-20$ & $10-15$ & $10-15$ \\
$\begin{array}{c}\text { Benefits in useful mineral recovery } \\
\text { compared to conventional } \\
\text { crushing: flotation }\end{array}$ & $\%$ & $2-8$ & No data & $15-70$ \\
$\begin{array}{c}\text { Plant-scale operation of the technology } \\
\text { Energy savings compared to conventional }\end{array}$ & $\%$ & $1-4$ & $5-20$ & up to 20 \\
$\begin{array}{c}\text { crushing circuit } \\
\begin{array}{c}\text { Capacity increases compared to } \\
\text { conventional crushing circuit }\end{array}\end{array}$ & $\%$ & Yes & No & No \\
\hline
\end{tabular}

\section{Circuits Layout and Optimization}

\subsection{Design Assumptions}

A suitable circuit layout, with properly designed material flows among specific operations, including recycle streams, is of great significance in optimizing feed disintegration processes. Following the one overarching principle of mechanical processing: "do not crush unnecessarily", special attention is (or, at least, should be) paid to the by-passing of fully or sufficiently liberated particles [18]. This is especially true for comminution techniques that cause greater generation of micro-cracks during grain disintegration processes which may contribute to higher liberation. Such materials are proceeded to pre-concentration, where some share of useful minerals can be quickly recovered. Such an approach can be characterized by the following effects: 
- A reduction in the capacity requirements of downstream grinding stage(s), which allows the installation of smaller grinding devices. More intense disintegration occurs in upstream crushing processes, which requires much less energy than grinding operations (Figure 2). The Figure gives a general idea of relationship between the size of treated material and the required energy for comminution. An exponential increase in the grinding energy can be observed, together with further decreasing the size of already fine material;

- The optional application of separation within comminution circuits, especially devices based on physical separation, such as jigs [19]. Jig separation has a long history of existence in technological circuits of mechanical processing or raw materials; however, many investigations aiming to improve the process for specific conditions and individual materials have been carried out $[20,21]$. This cost-efficient technology may give favorable results in the extraction of useful mineral amongst certain particle size fractions. Available results also confirm the potential for the separation of materials with relatively low differences in densities, provided specially designed devices are used [22].

- Decrease in the grinding energy consumption, which decreases the overall energy consumption of the circuit operational costs.

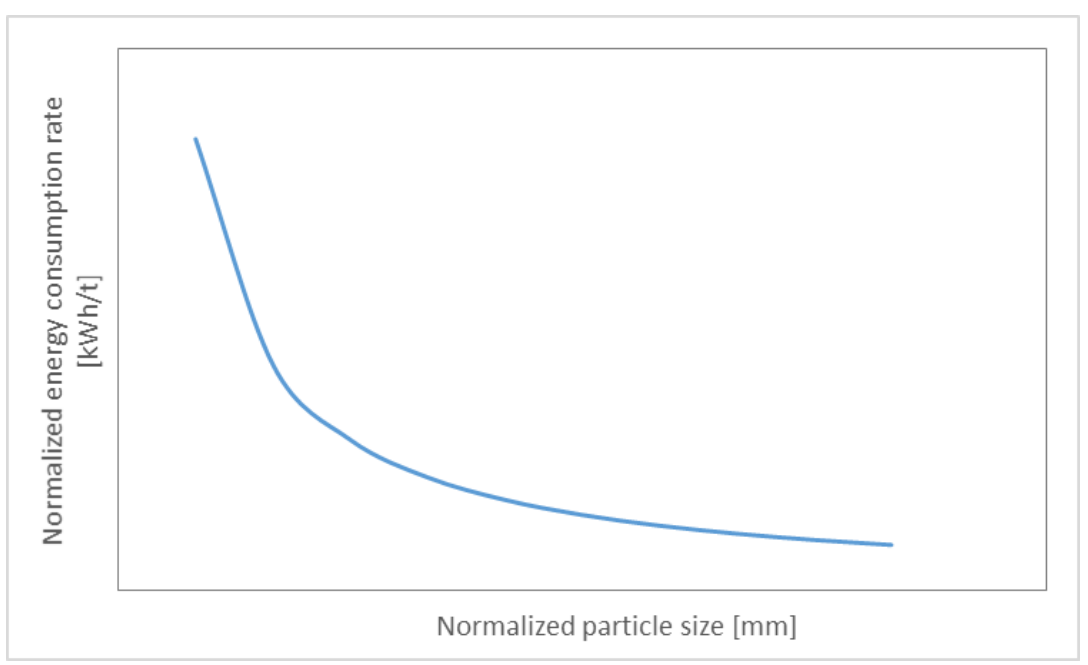

Figure 2. Relationship between energy usage for breaking and the size of treated particles.

Economic benefits include a reduction in CAPEX due to the possibility of the installation of smaller size devices, as well as contributing to the reduction in a major component of OPEX.

Such non-conventional layouts-i.e., where the breakage is more intensive on earlier comminution stages-are popular, especially in HPGR-based circuits. The relative energy savings in such configurations may reach $25 \%$ [23].

\subsection{Simulation in Mineral Processing}

Nowadays, many techniques and methods supporting the design, efficient operation, and performance assessment of mechanical processing are used in investigations. Among the most significant characteristics determining the effectiveness of comminution operations are particle breakage intensity and size reduction ratio, the size distribution of products, productivity, energy consumption, wear of liners, and movable parts of machines and others $[24,25]$. These can be distinguished following major directions in the modeling of mineral processing:

- Simulation tools and techniques showing models of behavior of grained material during the specific process, operation of a device, interactions amongst particles of the material, and interactions between the material and device. Various numerical 
techniques can be used in these simulations. The Discrete Element Method (DEM) is an especially popular technique used for this process, as well as in other disciplines outside mineral processing.

- Models capable of predicting the specific results of process performance. These include the approximation of particle size of comminution product, screening efficiency, comminution ratio, volume of material recycle, and others. These models are either based on theoretical distributions of random variables with confirmed applications in mineral processing or utilize principles of mathematical modeling.

- Optimization tools and applications based on the principles of mathematical and statistical modeling [26-28].

Modeling and simulation techniques for mapping the behavior of discrete mediums, such as grained materials, have become useful and powerful tools as the computational power and potentials of dedicated hardware accelerated in the last few decades. As a result, it is now possible to carry out very large numbers of calculations in very short time sequences for each modeled element. It is also now possible to characterize shortdistance interactions (i.e., particle-particle, particle-device) as well as long-range impacts, (i.e., gravity, electrostatic, magnetic, or other forces). The mentioned DEM method gained significant popularity in the modeling of various enrichment processes, and many examples concerning this issue are present in the literature.

The mineral processing constitutes only a fraction of the wide practical usage of this simulation technique, but some significant aspects of mineral processing were covered to some extent:

- Description of granular material flow in comminution processes;

- $\quad$ Potential prediction of particle size distribution for selected crushing products;

- Equipment design on the basis of analyzed process behavior;

- Simulation of conveyor transportation operations;

- Description of motion of particles in selected processes of gravitational separation.

There are, however, gaps and challenges for this method, especially in the simulation of fine and very fine particle motion, (i.e., in fine grinding processes). The problem is that a number of particles in simulation is limited, what requires the use of a method of extrapolation, especially for finer sizes.

\section{Modeling Approach}

The use of the correct modeling approach assists in the description of an operation, as well as the results achieved for specific operations in mineral processing. These have significant cognitive meaning, especially for conditions beyond the operational regime, such as an increased throughput, exceeded values of operational parameters of devices (i.e., increased $F_{\mathrm{sp}}$ in HPGR, higher rotational speed of shaft in impactors, higher/lower amplitude/frequency of vibration screen), and others. These situations, however, are undesirable and efforts have been made to eliminate them or at least to limit their impact on the process course. The issue of greater significance is the possibility of the assessment results of mechanical processing proceeded through specific operation. Comminution results seem to be the most important among them, and the most popular approach consists in approximation of PSD of crushing products [29]. The second significant issue seems to be assessment of the useful mineral liberation degree, but nowadays it appears that only analytical methods utilizing scanning electron microscopy (SEM), such as MLA, can be effective. The PSD approximation method is not new and has been present in mineral processing investigations for decades. It consists of the assumption that the act of particle breakage is a kind of probability, especially concerning the size of newly created particles in the crushing product [30,31]. The approximation of crushing results technically utilize the Least Squares method (LS) and can be performed by means of various mathematical functions (distributions). Most of these have a confirmed application into a specific type and size of feed material and crushing device [32]. For example, the Weibull (or RRB) distribution was introduced into mineral processing in the 1930s [33] 
for the assessment of the particle size of crushing products. Log-norm distribution, in turn, has found application for the approximation of fine crushing (grinding) products [34]. In recent decades, functions previously used in other disciplines have also been used in mineral processing. The logistic distribution could be such an example. Approximation functions used in the estimation of particle size distribution of crushing products usually have two parameters, denoted as shape and scale parameters. It is worth mentioning that the application of theoretical distributions with a greater number of parameters may improve the modeling results; however, problems can appear in the interpretation of results, especially when the model is used in more general cases. So-called "censored distributions", (i.e., theoretical distributions with additional parameters that limits the particle size of the product by introducing minimum or maximum particle $\left(\mathrm{d}_{\min }\right.$ or $\left.\mathrm{d}_{\max }\right)$ ) can be more efficient in some cases [35].

The fitting accuracy can be assessed through the estimation error $s_{r}$, which is defined through Formula (1).

$$
s_{r}=\sqrt{\frac{\sum_{i=1}^{n}\left(y_{i_{\text {emp }}}-y_{i_{\text {mod }}}\right)^{2}}{n-2}},
$$

where $y_{i_{e m p}}$, empirical data; $y_{i_{\text {mod }}}$, modeling data; $n$, number of data points.

An exemplary approximation of the particle size distribution of a HPGR product was performed using three approximation functions, as presented in Table 2.

Table 2. Approximation functions used in fitting and the obtained results.

\begin{tabular}{cc}
\hline Approximation Function & Approximation Formula \\
\hline Weibull's distribution & $F(d)=1-\exp \left(-\frac{d}{d_{0}}\right)^{n}$ \\
Log-norm distribution & $F(d)=\frac{1}{2 \pi} \int_{-\alpha}^{t} \exp \left(-\frac{t^{2}}{2}\right) d t, \quad t=\frac{\ln \left(\frac{d}{d_{0}}\right)}{\sigma}$ \\
Logistic distribution & $F(d)=\frac{1}{1+b \cdot \exp (-c \times d)}$ \\
\hline
\end{tabular}

The testing program included the crushing of feed material in the laboratory HPGR device under two values of operational pressing forces F: 15 and $10 \mathrm{kN}$. The width of rolls $\mathrm{L}=100 \mathrm{~mm}$, diameter $\mathrm{D}=300 \mathrm{~mm}$. Three samples of the same feed material with a similar particle size distribution were crushed in the HPGR press device under various conditions in order to obtain products with diverse particle size distributions:

- $\quad$ product 1: the material with increased content of fines, the feed was crushed twice under base pressing force $(15 \mathrm{kN})$;

- $\quad$ product 2: the material with relatively lower content of fines-crushed under lower pressing force $(10 \mathrm{kN})$;

- product 3: the material with balanced content of individual particle size fractions-crushed once under base pressing force $(15 \mathrm{kN})$.

The PSD of all products, along with fittings with three functions, are presented in Figures 3-5.

The test results clearly show that the results of comminution depend on the manner of crushing device operation. However, it is also evident that the results of the comminution in each case can be approximated with different effects depending on the function used in calculations. It appears evident that crushing products with an increased content of fines can be described well through the use of Weibull's formula. The HPGR crushing product obtained for average crushing force turned out to be very well characterized by logistic distribution.

When the feed material was crushed under a lower pressing force, the particle size composition of the obtained product could be adequately described with the use of a log-normal distribution. Detailed characteristics of the approximation in terms of fitting error values are given in Table 3. 


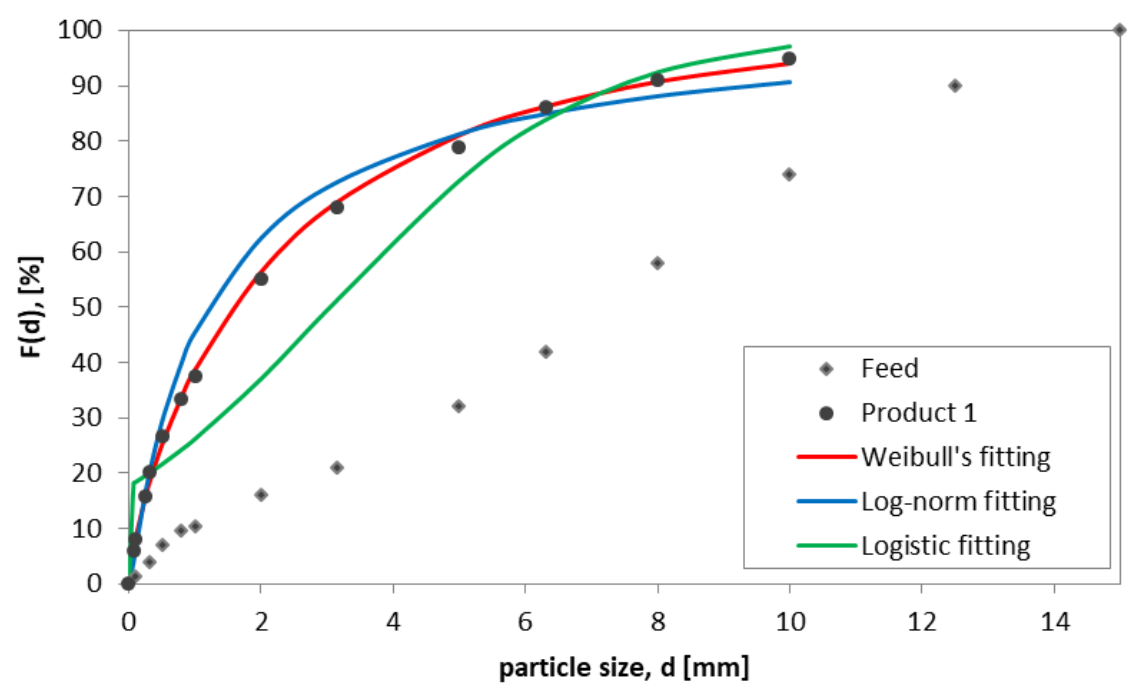

Figure 3. Fitting results for product 1 .

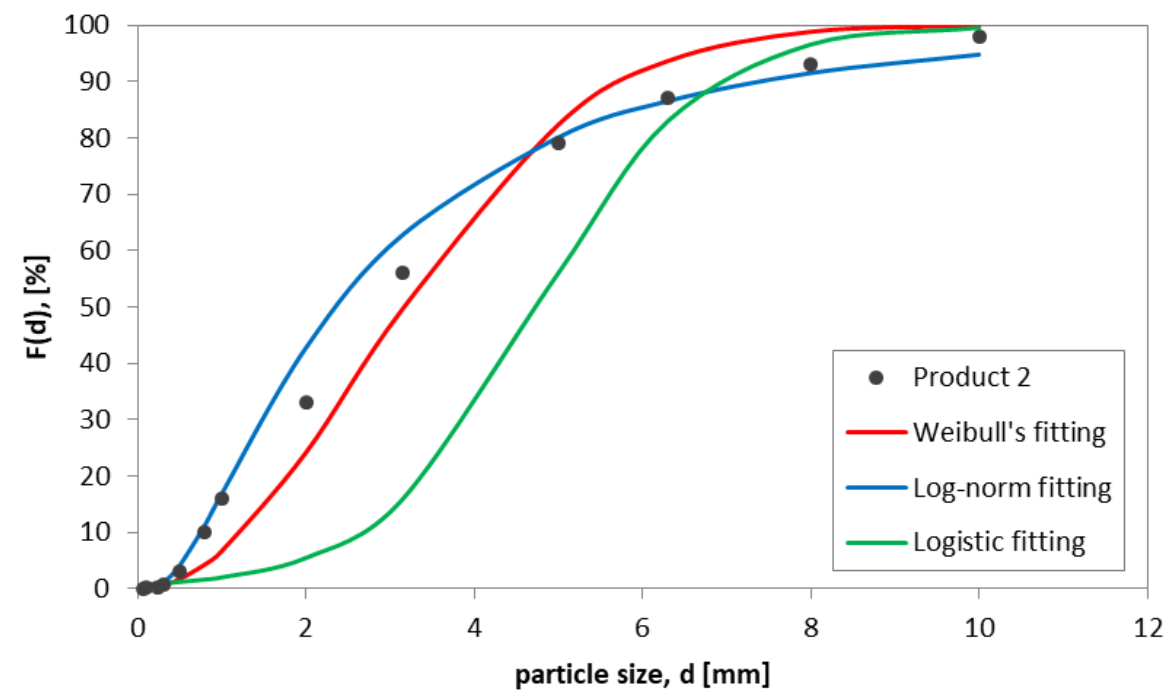

Figure 4. Fitting results for product 2 .

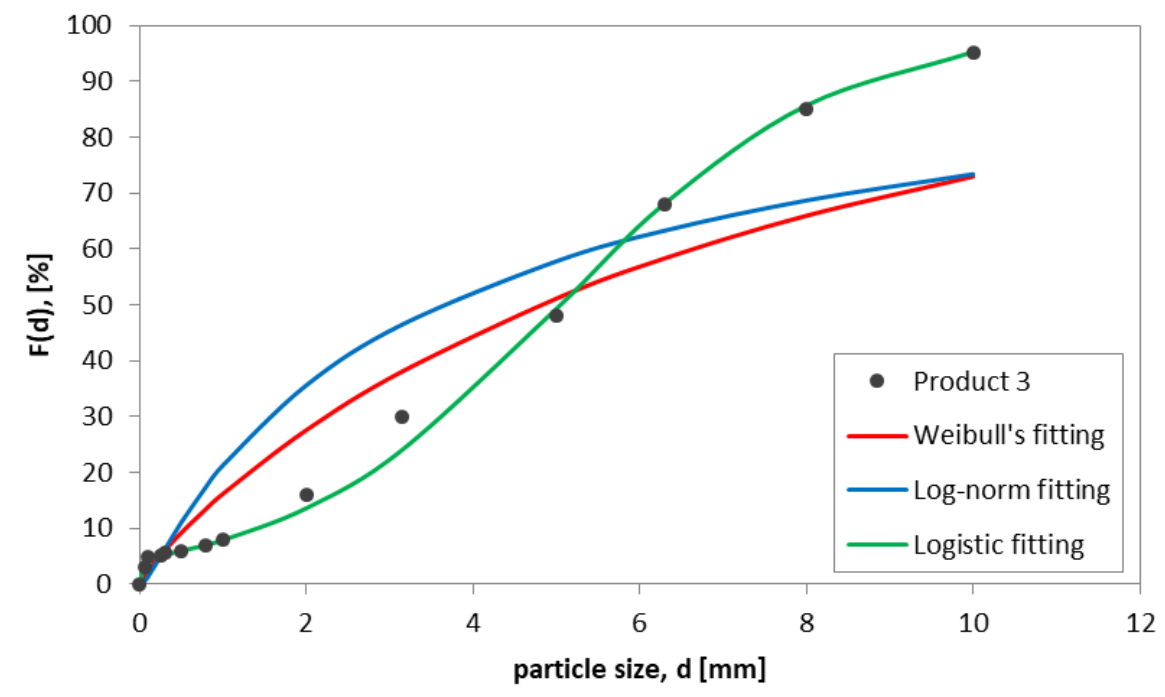

Figure 5. Fitting results for product 3 . 
Table 3. Values of fitting errors for individual crushing products.

\begin{tabular}{cccc}
\hline \multirow{2}{*}{ Approximation Function } & \multicolumn{3}{c}{ Approximation Error } \\
\cline { 2 - 4 } & Product 1 & Product 2 & Product 3 \\
\hline Weibull's distribution & 1.67 & 7.78 & 15.25 \\
Log-norm distribution & 4.59 & 3.79 & 12.92 \\
Logistic distribution & 10.26 & 17.06 & 2.05 \\
\hline
\end{tabular}

\section{Environmental Issues}

As previously mentioned, negative impacts of mineral processing (and mining in general) are evident in various aspects. One of the most commonly described seems to be the dust pollution. A wide range of investigations in this area can be found in the literature, particularly those concerning the operation of the mining industry. These include investigations into dust emissions directly from the open pit mines or quarries resulting from their routine operation [36-39], emissions from tailing deposits [40] or transport of run-of-mine and aggregate products, including loading and unloading of material [41]. Operations of mechanical processing are characterized by various rates of dust emission, depending on the size of particle, type of device and its productivity, and crushing stage [42]. Typical relationships between the size of handling material and the total amount of dust generated are described by means of exponential function with negative relationships between the size of the particle and emission volume (Formula (2)):

$$
E_{T S P}=\frac{A}{d^{B}}
$$

where $E_{T S P}$, total emission of dust particles $\left(\mathrm{mg} / \mathrm{m}^{3}\right) ; d$, particle size $(\mathrm{mm}) ; A, B$, coefficients. Selected values of total dust emissions according to different sources are presented in Table 4.

Table 4. The TSP emission of selected devices according to various investigations.

\begin{tabular}{|c|c|c|}
\hline Processing Stage & $\begin{array}{c}\text { Relative Emission } \\
\text { (Primary Crushing = 1) [43] }\end{array}$ & Total Emission $\left[\mathrm{mg} / \mathrm{m}^{3}\right]$ [44] \\
\hline Primary crushing & 1 & 2.8 \\
\hline Secondary crushing & $3[45]$ & 3.2 \\
\hline Tertiary crushing & 51 (dry), 2 (wet) & 30 \\
\hline Screening (dry) & 214 & No data \\
\hline Screening (wet) & 12 & No data \\
\hline
\end{tabular}

The dust emission is often described as TSP or total suspended particulates. It denotes particles with a diameter smaller than $20 \mu \mathrm{m}$, as larger grains usually fall to the ground quickly and do not constitute the air contaminants.

To overcome this negative impact, many models which determine and predict the volume of dust emissions have been developed. These models consider the general principles $[46,47]$ and are built on empirical data relating to the specific site $[48,49]$. The formulas were devised on the bases of empirical data, the specific location of a mine, and atmospheric conditions. Parameters characterizing properties of the material (such as moisture and silt contents) were taken into account.

Noise emission is another important factor that affects the life of local society around the mineral processing plant, as well the working conditions at the site [50]. The limitation of this source of pollution seems to be relatively less complex technically than in the case of dust, and typically involves building suitable soundproof and sound-absorbing screens and walls. 


\section{Summary}

Mining and mineral processing are relevant for numerous disciplines and have significant impacts on the operation of various sectors of the economy, especially in raw material management within the metal value chain production. An increasing number of mining companies are facing problem concerning decreases in orebody grades and finer mineralization due to the depletion of deposits. At such a time, the idea of zero-waste economy gains importance and popularity. These aspects give rise to the development of mineral processing technology and the more efficient utilization of raw material. Efforts are focusing more on the effective utilization of recent techniques in mechanical processing than on the introduction of brand new feed material treatment technology. This article presented select problems that are especially popular in contemporary mineral processing at the stage of mechanical processing. The increased effectiveness of specific operations can be observed from different scopes, but energy efficiency and useful mineral loss seem to be of major importance. The development of computational techniques and new methods of material analysis will undoubtedly create new opportunities and potential improvements of operation effectiveness.

Not all directions of development have been covered, and the visual analysis and characterization of grained materials are only mentioned. Nevertheless, the results of many investigations and the operational practice of mineral processing plants, show that the stage of the mechanical processing of raw materials preliminarily impacts the potential of effective separation and useful metal recovery.

It is also necessary to highlight major critical aspects and gaps that should be the objects of investigations both in the near future and from a longer-term perspective. There is some consensus that the high energy consumption of comminution processes stands among the most significant issues within the field. However, the problem lies in the more efficient utilization of energy for the breakage and limitation of losses, particularly in fine grinding operations. This is connected to the need for handling the fine mineralized feed material. The scale problem also needs to be solved in electromagnetic grinding, as well as in high-voltage pulse breakage. To some extent, this is also valid for other operations of mechanical processing, such as vibrating mills, SAG and AG grinding, and HPGR. It is also necessary to remember that, when facing the depletion of deposits, (Table 5) it is harder to maintain the overarching aim of mineral processing: achieving a high level of useful mineral recovery.

Table 5. World average grades of selected ore minerals [51,52].

\begin{tabular}{cccc}
\hline Type of Ore & Unit & Average Grade in 80's & Current Average Grade \\
\hline Copper & $\%$ & 1.5 & 0.62 \\
Lead + Zinc & $\%$ & 8 & 6.05 \\
Nickel & $\%$ & 4 & 1 \\
Gold (surface mining) & $\mathrm{g} / \mathrm{Mg}$ & 3.5 & 2 \\
\hline
\end{tabular}

Funding: This research received no external funding.

Conflicts of Interest: The author declares no conflict of interest. 


$\begin{array}{ll}\text { Abbreviations } \\ \text { HPGR } & \text { high-pressure grinding rolls } \\ \text { ROM } & \text { run-of-mine } \\ \text { CAPEX } & \text { capital expenditure } \\ \text { OPEX } & \text { operational expenditure } \\ \text { DEM } & \text { discrete element method } \\ \text { WOS } & \text { Web of Science (database) } \\ \text { PSD } & \text { particle size distribution } \\ \text { SEM } & \text { scanning electron microscopy } \\ \text { MLA } & \text { mineral liberation analyzer } \\ \text { LS } & \text { least squares (method) } \\ \text { RRB } & \text { Rosin-Rammler-Bennett (distribution) } \\ \text { TSP } & \text { total suspended particulates } \\ \text { SAG } & \text { semi-autogenous grinding } \\ \text { AG } & \text { autogenous grinding }\end{array}$

\section{References}

1. Gawenda, T. Zasady Doboru Kruszarek Oraz Układów Technologicznych w Produkcji Kruszyw łamanych. Monography No. 304; AGH Public House: Cracow, Poland, 2015.

2. Tromans, D. Mineral comminution: Energy efficiency considerations. Min. Eng. 2008, 21, 613-620. [CrossRef]

3. Fuerstenau, D.W.; Abouzeid, Z.M. The energy efficiency of ball milling in comminution. Int. J. Min. Proc. 2002, 67, 161-185. [CrossRef]

4. Gawenda, T. The influence of rock raw materials comminution in various crushers and crushing stages on the quality of mineral aggregates. Miner. Res. Manag. 2013, 29, 53-65. [CrossRef]

5. Gawenda, T. Comparative Analysis of Mobile and Stationary Technological Sets for Screening and Grinding. Ann. Set Environ. Prot. 2013, 15, 1318-1335.

6. Bearman, K. Step change in context of comminution. Min. Eng. 2013, 43-44, 2-11. [CrossRef]

7. Morrell, S. Predicting the overall specific energy requirement of crushing, high pressure grinding roll and tumbling mill circuits. Min. Eng. 2009, 22, 544-549. [CrossRef]

8. Wang, C.; Nadolski, S.; Mejia, O.; Drozdiak, J.; Klein, B. Energy and cost comparison of HPGR based circuits with the SABC circuit installed at the Huckleberry Mine. In Proceedings of the 45th Annual Canadian Mineral Processors Operators Conference, Ottawa, ON, Canada, 22-24 January 2013; pp. 121-135.

9. Klingmann, H.L. HPGR benefits at Golden Queen Soledad Mountain gold heap leaching project. In Proceedings of the Randol Innovative Metallurgy Forum, Perth, Australia, 21-24 August 2005.

10. Yin, W.; Tang, Y.; Ma, T.; Zuo, W.; Yao, J. Comparison of sample properties and leaching characteristics of gold ore from jaw crusher and HPGR. Min. Eng. 2017, 111, 140-147. [CrossRef]

11. Tang, Y.; Yin, W.Z.; Wang, J.X.; Zuo, W.R.; Cao, S.H. Effect of HPGR comminution scheme on particle properties and heap leaching of gold. Canadian Metallurg. Quart. 2020, 59, 1-7. [CrossRef]

12. Saramak, D.; Saramak, A. Potential Benefits in Copper Sulphides Liberation through Application of HRC Device in Ore Comminution Circuits. Minerals 2020, 10, 817. [CrossRef]

13. Baum, W.; Ausburn, K. HPGR comminution for optimization of copper leaching. Min. Met. Process. 2011, 28, 77-81. [CrossRef]

14. Ghorbani, Y.; Mainza, A.N.; Petersen, J.; Becker, M.; Franzidis, J.-P.; Kalala, J.T. Investigation of particles with high crack density produced by HPGR and its effect on the redistribution of the particle size fraction in heaps. Min. Eng. 2013, 43-44, 44-51. [CrossRef]

15. Anders, U. Development and prospects of mineral liberation by electrical pulses. Int. J. Min. Proc. 2010, 97, 31-38. [CrossRef]

16. Gao, P.; Yuan, S.; Han, Y.; Li, S.; Chen, H. Experimental Study on the Effect of Pretreatment with High-Voltage Electrical Pulses on Mineral Liberation and Separation of Magnetite Ore. Minerals 2017, 7, 153. [CrossRef]

17. Wolosiewicz-Głąb, M.; Ogonowski, S.; Foszcz, D.; Gawenda, T. Assessment of classification with variable air flow for inertial classifier in dry grinding circuit with electromagnetic mill using partition curves. Physicochem. Probl. Min. Proc. 2018, 54, 440-447.

18. Saramak, D.; Tumidajski, T.; Gawenda, T.; Naziemiec, Z. Ekologiczne aspekty związane z efektami wysokociśnieniowego rozdrabniania w prasach walcowych. Ann. Set Environ. Prot. 2013, 15, 1580-1593.

19. Phengsaart, T.; Ito, M.; Hamaya, N.; Tabelin, C.B.; Hiroyoshi, N. Improvement of jig efficiency by shape separation, and a novel method to estimate the separation efficiency of metal wires in crushed electronic wastes using bending behavior and "entanglement factor". Min. Eng. 2018, 129, 54-62. [CrossRef]

20. Ambrós, W.M. Jigging: A Review of Fundamentals and Future Directions. Minerals 2020, 10, 998. [CrossRef]

21. Stempkowska, A.; Gawenda, T.; Naziemiec, Z.; Ostrowski, K.; Saramak, D.; Surowiak, A. Impact of the geometrical parameters of dolomite coarse aggregate on the thermal and mechanic properties of preplaced aggregate concrete. Materials 2020, 13, 4358. [CrossRef] [PubMed]

22. Gawenda, T. Układ Urządzeń do Produkcji Kruszyw Foremnych. Patent PL 2019, 233689, B1. (In Polish) 
23. Rosario, P.P. Technical and economic assessment of a non-conventional HPGR circuit. Min. Eng. 2017, 103-104, 102-111. [CrossRef]

24. Weerasekara, N.S.; Powell, M.S.; Cleary, P.W.; Tavares, L.M.; Evertsson, M.; Morrison, R.D.; Quist, J.; Carvalho, R.M. The contribution of DEM to the science ofcomminution. Powder Technol. 2013, 248, 3-24. [CrossRef]

25. Tavares, L.M.; Rodrigues, V.; Carles, M.S. Padros, B. An effective sphere-based model for breakage simulation in DEM. Powder Technol. 2021, 392, 473-488. [CrossRef]

26. Jovanovic, I.; Nikolic, D.; Savic, M.; Zivkovic, Z. Batch composition optimization for the copper smelting process on the example of copper smelter in BOR. Environ. Eng. Manag. J. 2016, 15, 791-799. [CrossRef]

27. Jovanovic, I.; Savic, M.; Zivkovic, Z.; Boyanov, B.S. An Linear Programming Model for Batch Optimization in the Ecological Zinc Production. Environ. Model. Assess. 2016, 21, 455-465. [CrossRef]

28. Saramak, D.; Tumidajski, T.; Skorupska, B. Technological and economic strategies for the optimization of Polish electrolytic copper production plants. Min. Eng. 2010, 23, 757-764. [CrossRef]

29. Naziemiec, Z.; Saramak, D. Application of partition curves in the assessment of mineral products classification processes. Min. Sci. 2015, 22, 119-129.

30. Lowrison, G.C. Crushing and Grinding; Butterworths: London, England, 1974.

31. Brożek, M.; Mączka, W.; Tumidajski, T. Mathematical Models of Grinding Processes; AGH Publishing House: Cracow, Poland, 1995. (In Polish)

32. Tumidajski, T.; Saramak, D. Methods and Models of Mathematical Statistics in Mineral Processing; AGH Publishing House: Cracow, Poland, 2009; pp. 1-304.

33. Rosin, P.; Rammler, E. The laws governing the fineness of powdered coal. J. Inst. Fuel 1933, 7, $29-36$.

34. Kołomogorow, A.N. Über das logarithmisch normale Verteilungsgesetz der Dimensionen der Teilchen bei Zerstückelung. Dokl. Akad. Nauk SSSR 1941, 31, 99-101.

35. Nad, A.; Brożek, M. Application of three-parameter distribution to approximate the particle size distribution function of comminution products of dolomitic type of copper ore. Arch. Min. Sci. 2017, 62, 411-422. [CrossRef]

36. Chakraborty, M.K.; Ahmad, M.; Singh, R.S.; Pal, D.; Bandopadhyay, C. Determination of the emission rate from various opencast mining operations. Environ. Model. Softw. 2002, 17, 467-480. [CrossRef]

37. Huertas, J.; Camacho, D.; Huertas, M. Standardized emissions inventory methodology for open pit mining areas. Environ. Sci. Pollut. Res. 2012, 19, 2784-2794. [CrossRef]

38. Chang, C.-T.; Chang, Y.-M.; Lin, W.-Y.; Wu, M.-C. Fugitive dust emission source profiles and assessment of selected control strategies for particulate matter at gravel processing sites in Taiwan. J. Air Waste Manag. Assoc. 2012, 60, 1262-1268. [CrossRef]

39. Saramak, A.; Naziemiec, Z. Determination of dust emission level for various crushing devices. Min. Sci. 2019, 26, 45-54. [CrossRef]

40. Cigagna, M.; Dentoni, V.; Grosso, B.; Massacci, G. Emissions of Fugitive Dust from Mine Dumps and Tailing Basins in SouthWestern Sardinia. In Mine Planning and Equipment Selection; Springer: Cham, Switzerland, 2014.

41. Tian, S.; Liang, T.; Li, K. Fine road dust contamination in a mining area presents a likely air pollution hotspot and threat to human health. Environ. Intern. 2019, 128, 201-209. [CrossRef]

42. Saramak, A. Comparative Analysis of Selected Types of Crushing Forces in Terms of Dust Emission. Inżynieria Miner. J. Pol. Miner. Eng. Soc. 2019, 2, 151-154.

43. Cecala, A.B.; O’Brien, A.D.; Schall, J.; Colinet, J.F.; Franta, R.J.; Schultz, M.J.; Haas, E.J.; Robinson, J.E.; Patts, J.; Holen, B.M.; et al. Dust Control Handbook for Industrial Minerals Mining and Processing, 2nd ed.; National Institute for Occupational Safety and Health: Pittsburgh, PA, USA, 2019.

44. Saramak, D.; Wasilewski, S.; Saramak, A. Influence of copper ore comminution in HPGR on downstream minerallurgical processes. Arch. Metall. Mater. 2017, 62, 1689-1694. [CrossRef]

45. Evaluation of Fugitive Dust Emissions from Mining-Report; PEDCo-Environmental Specialists Inc.: Cincinnati, OH, USA, 1976.

46. Holmes, N.S.; Morawska, L.A. Review of dispersion modeling and its application to the dispersion of particles: An overview of different dispersion models available. Atmos. Environ. 2006, 40, 5902-5928. [CrossRef]

47. Prakash, J.; Singh, G.; Pal, A.K. Air pollution dispersion modeling performance for mining complex. Environ. We Int. J. Sci. Technol. 2010, 5, 205-222.

48. Chaulya, S.K.; Chakraborty, M.K.; Ahmad, M.; Singh, R.S.; Bondyopadhay, C.; Mondal, G.C.; Pal, D. Development of empirical formulae to determine emission rate from various opencast coal mining operations. Water Air Soil Pollut. 2002, 140, 21-55. [CrossRef]

49. Chaulya, S.K.; Ahmad, M.; Singh, R.S.; Bandopadhyay, L.K.; Bondyopadhay, C.; Mondal, G.C. Validation of two air quality models for Indian mining conditions. Environ. Monit. Assess. 2002, 82, 23-43. [CrossRef] [PubMed]

50. Saramak, A.; Naziemiec, Z.; Saramak, D. Analysis of noise emission for selected crushing devices. Min. Sci. 2016, 23, 145-154. [CrossRef]

51. Saramak, D. Simulation of comminution effects in HPGR for the feed material variable content of fine particles. Miner. Res. Manag. 2015, 31, 123-136.

52. Calvo, G.; Mudd, G.; Valero, A.; Valero, A. Decreasing Ore Grades in Global Metallic Mining: A Theoretical Issue or a Global Reality? Resources 2016, 5, 36. [CrossRef] 